\title{
The Nutritional Contributions of Some Forest Edible Seeds to Food Security
}

\author{
* Dawaki, S.A ${ }^{1}$, Abdulhamid, B. ${ }^{1}$, Abubakar, E.M ${ }^{2}$ \\ ${ }^{I}$ Department of Forestry Technology, Audu Bako College of Agriculture, Dambatta, Kano State, Nigeria \\ ${ }^{2}$ Department of Forestry Technology, College of Agriculture, Yelwa, Bauchi, Bauchi State, Nigeria
}

\author{
*Corresponding Author: Dawaki, S.A, Department of Forestry Technology, Audu Bako College of \\ Agriculture, Dambatta, Kano State, Nigeria.
}

\begin{abstract}
Ensuring access to adequate and nutritious food produced in an environmentally and socioculturally sustainable manner, this study was aimed to investigate the nutrient potential of some edible wild plants sourced from northern region of Nigeria. The seeds of Adansonia digitata (Lin), Afzelia africana, and Terminalia catappa $(L)$ were analyzed in water-soluble forms to determine their mineral compositions (Calcium, phosphorus, potassium, iron, magnesium and iodine) and vitamin compositions (A, $C$ and $E$ ). Atomic absorption spectrophotometer and titration method showed that the seeds were found to be good sources of minerals. Calcium (789.61 $\pm 0.01 \mathrm{mg} / 100 \mathrm{~g})$, iron (422.00 $\pm 1.00 \mathrm{mg} / 100 \mathrm{~g})$, potassium (7233.50 \pm $3.50 \mathrm{mg} / 100 \mathrm{~g})$ and magnesium $(687.58 \pm 0.01 \mathrm{mg} / 100 \mathrm{~g})$ were high in T. catappa seeds while A. digitata seeds had $81.08 \pm 0.05 \mathrm{mg} / 100 \mathrm{~g}$ as the lowest contain of calcium. Iron (3.49 \pm 0.03$)$ and magnesium (3.59 \pm 0.01$)$ were low in A. africana seeds. The results showed that A. digitata seeds had high content of vitamins $A$ and $C$ while T. catappa seeds had the lowest vitamin contents. A. africana seeds had low contain of vitamin E $(0.74$ $\pm 0.01 \mathrm{mg} / 100 \mathrm{~g}$ ). Based on this results, the concentration of macro and micro nutrients in these lesser known edible wild seeds have promising potentials to alleviate the risk of some nutritional deficiency diseases in African countries. Also, the seeds are dietary source of vitamins A, C and E for human body. There is the need to assess the availability of the tree seeds and possible present of anti-nutrients.
\end{abstract}

Keywords: Edible seeds, Nutrients potential, Minerals and Vitamins.

\section{INTRODUCTION}

In most developing tropical countries the food situation is worsening owing to increasing population, shortage of fertile land, high prices of available staples, and restrictions on the importation of food [1]. This has resulted in a high incidence of hunger and malnutrition, a situation in which children and women, especially pregnant and lactating women are most vulnerable [2]. While every measure is being taken to boost food production by conventional agriculture, a lot of interest is currently being focused on the possibilities of exploiting the vast numbers of less familiar plant resources existing in the wild [3]. Many such plants have been identified, but the lack of information on their nutritive contents has limited the prospects for their utilization [4].

Edible wild tree seeds are a critical component in the quest for food and nutritional security. Indeed, tree products have always been an important part of people's diets. In many developing countries, leaves, fruits, seeds, nuts, flowers, shoots and roots from trees forest are traditionally eaten and add vitamins and minerals to diets. Most tree products are excellent sources of both macro- and micronutrients (minerals and vitamins), therefore contributing to reducing hunger and malnutrition. They often provide people with a food safety net in times of droughts, poor harvests and seasonal scarcity of other foods, and actively contributing to dietary needs.

Deficiency disease as a result of malnutrition is very common in developing countries. Malnutrition in Nigeria is mainly due to mismanagement and misappropriations of resources while in other developing nations are due to poverty. Inadequate minerals and vitamins intake are as a result of poor nutrition education. The consequences of malnutrition in the developing countries cannot be over emphasizing. This tragedy is mostly found in the rural areas and some urbans. This can be attributed to mere ignorance of food trees around the people. Approximately $33 \mathrm{~g}$ of protein are lost each day by the average adult male and can be replaced in the diet [5]. 
Discovery of alternative nutrient sources is a major need in Africa and Nigeria in particular. There are many forest seed species that have nutritive values and could possibly contributes to food security if given adequate research attention and sensitization. Underutilized foods could be used to meet world food security demands when properly processed for consumption. The wild food seeds rich in vitamins and minerals particularly legumes could effectively reduce the level of malnutrition among the developing nations. These wild seeds could be good nutrient sources if integrated fully into human nutrition.

\section{MATERials AND MeTHOdS}

\subsection{Study Area}

The study covered the eighteen Northern states of Nigeria where the selected seeds are available and use. Seeds evaluation was conducted in Food Biochemistry laboratory of the department of Food Science Technology, University of Agriculture Makurdi (UAM), located on longitude $8^{\circ} 33 \mathrm{~N}$, latitude $7^{\circ} 44 \mathrm{E}$ in Benue State which lies in the middle belt of Nigeria. Characterized by two distinct seasonsDry and Wet in the Southern guinea savannah. The climate of the area is tropical sub-humid climate with high temperatures, high humidity, the average maximum and minimum daily temperature of $35^{\circ}$ and $21{ }^{\circ} \mathrm{C}$ in wet season, $37^{\circ} \mathrm{C}$ and $16^{\circ} \mathrm{C}$ in dry season respectively. The mean annual rainfall value is $1000 \mathrm{~mm}$ to $1500 \mathrm{~mm}$. The vegetation of the area has been described as guinea savannah.

\subsection{Sample Preparation and Analysis}

Matured seeds were obtained from different forests within the region and stored in a polythene bags to prevent moisture loss and possible contamination during transportation to the laboratory. The samples were identified at the Forestry general laboratory, University of Agriculture Makurdi. The samples were prepared and used for minerals and vitamins analysis by washing with distilled water to remove all impurities and dried at room temperature to remove residual moisture. The samples were oven dried at $55{ }^{\circ} \mathrm{C}$ for $24 \mathrm{~h}$. The dried seeds were grounded into powder using a mortar and pestle and then sieved through 20 inch mesh sieves and analyzed using the standard procedures of the Association of Official Analytical Chemists [6]. All analysis was done in triplicates. The minerals and vitamins of the selected seeds were determined using the standard procedures of the Association of Official Analytical Chemists [7]. Analytical reagent nitric acid, hydrochloric acid and standard iron solution were used.

\subsection{Determination of Mineral and Vitamin Contents}

The mineral contents of samples were determined using Atomic Absorption Spectrophotometer, according to the procedure described by AOAC [7]. One gram of each samples was digested by wetdigestion method using combination of percholic acid, nitric acid and sulphuric acid mixture [8] in the ratio 8:2:1, respectively, and filtered. The digest obtained was used for the various analyses. Deionized water was used to avoid interferences from the minerals that may be contained in the water. The filtrate was made up to mark in a $5 \mathrm{ml}$ volumetric flask. The filtered solution was loaded to an Atomic Absorption Spectrophotometer. The standard curve for each mineral was prepared from known standards and the mineral value of samples estimated against that of the standard curve. All the mineral elements were determined on spectrophotometer using the filter corresponding to each mineral element.

Vitamins $\mathrm{A}, \mathrm{C}$ and $\mathrm{E}$ were analyzed in juices formed on $5 \mathrm{~g}$ sample and determined by filtration method described by Pearson [8] using Whatman filter paper. The filtrate was titrated hot (80 to 90 ${ }^{\circ} \mathrm{C}$ ) that persists for 30 seconds (using Titration method).

\subsection{Statistical Analysis of Data}

Data generated from all analyses were subjected to statistical analysis using Excel version 2010 through one way analysis of variance (ANOVA). Significant difference between samples was tested at $\mathrm{P}<0.05$.

\section{RESULTS}

Table 1, shows the mineral contents of the selected edible forest seeds in the study area. The calcium content of the selected seeds ranged from $81.08 \pm 0.05 \mathrm{mg} / 100 \mathrm{~g}$ to $789.61 \pm 0.01 \mathrm{mg} / 100 \mathrm{~g}$. The calcium contend of $A$. digitata seeds were found to be the least $(81.08 \pm 0.05 \mathrm{mg} / 100 \mathrm{~g})$ while $T$. 
cattapa was the highest $(789.61 \pm 0.01 \mathrm{mg} / 100 \mathrm{~g})$. The Potassium content of the selected edible forest seeds differed significantly $(\mathrm{P}<0.05)$, with the highest potassium content of $7233.50 \pm 3.50 \mathrm{mg} / 100 \mathrm{~g}$ from $T$. cattapa seeds. Iron contents of $A$. africana, A. digitata and T. cattapa ranged between $3.49 \pm$ 0.03 (A. africana) and $422.0 \pm 1.00 \mathrm{mg} / 100 \mathrm{~g}$ ( $T$. cattapa) with phosphorus and magnesium had the mineral composition that ranged from $9.48 \pm 0.01 \mathrm{mg} / 100 \mathrm{~g}$ (from A. africana) to $112.55 \pm 0.35$ $\mathrm{mg} / 100 \mathrm{~g}$ (from A. digitata) and $3.59 \pm 0.01 \mathrm{mg} / 100 \mathrm{~g}$ (from A. Africana) to $687.58 \pm 70.01 \mathrm{mg} / 100 \mathrm{~g}$ (from T. cattapa) respectively. While iodine was found to be $82.4 \pm 0.01$ as the least from A. digitata and $134.04 \pm 0.03 \mathrm{mg} / 100 \mathrm{~g}$ was the highest iodine content from $A$. africana among the study seeds in the study area. The mineral compositions of the study seeds were analyzed and the ANOVA result showed significantly different with P-values less than 0.05.

Table 1. Mineral Elements Composition of some Wild Edible Seeds in the Study Area

\begin{tabular}{|c|c|c|c|c|c|c|}
\hline \multicolumn{3}{|c|}{ Tree specie } & \multicolumn{4}{|c|}{ Minerals (mg/100 g) } \\
\hline & $\mathbf{C a}$ & $\mathbf{K}$ & $\mathrm{Fe}$ & $\mathbf{P}$ & Mg & I \\
\hline $\begin{array}{l}A . \\
\text { africana }\end{array}$ & $322.00 \pm 1.00 \mathrm{a}$ & $1351.00 \pm 1.00 \mathrm{a}$ & $3.49 \pm 0.03 a$ & $9.48 \pm 0.01 \mathrm{a}$ & $3.59 \pm 0.01 \mathrm{a}$ & $134.04 \pm 0.03 \mathrm{a}$ \\
\hline $\begin{array}{l}\text { A. } \\
\text { digitata }\end{array}$ & $81.08 \pm 0.05 \mathrm{~b}$ & $1381.70 \pm 1.35 \mathrm{~b}$ & $6.94 \pm 0.02 b$ & $112.55 \pm 0.35 \mathrm{~b}$ & $70.29 \pm 0.03 b$ & $84.94 \pm 0.01 \mathrm{~b}$ \\
\hline $\begin{array}{l}\text { cattapa } \\
\end{array}$ & $789.61 \pm 0.01 \mathrm{c}$ & $7233.50 \pm 3.50 \mathrm{c}$ & $422.00 \pm 1.00 \mathrm{c}$ & $15.12 \pm 0.02 \mathrm{c}$ & $68.58 \pm 70.01 \mathrm{c}$ & $82.44 \pm 0.01 \mathrm{c}$ \\
\hline
\end{tabular}

Means on the same column with different superscript differ significantly $(p<0.05)$

Where: $\mathrm{Ca}=$ calcium, $K=$ potassium, $\mathrm{Fe}=$ iron, $P=$ phosphorus, $M g=$ magnesium and $I=$ iodine

Table 2 shows vitamins $\mathrm{A}, \mathrm{C}$ and $\mathrm{E}$ contents of the selected forest edible seeds from the study area. The ANOVA result showed significantly different $(\mathrm{P}<0.05)$ from the vitamin contents between forest tree seeds. Vitamin A content determined from the selected seeds ranged from $0.91 \pm 0.00 \mathrm{mg} / 100 \mathrm{~g}$ as the least content from $T$. cattapa seed to $322.50 \pm 1.50 \mathrm{mg} / 100 \mathrm{~g}$ as the highest content from $A$. digitata seeds. Vitamin $\mathrm{C}$ composition was ranged from $0.05 \pm 0.00 \mathrm{mg} / 100 \mathrm{~g}$ as the least evaluated from $T$. cattapa seeds to $522.50 \pm 1.50 \mathrm{mg} / 100 \mathrm{~g}$ as the highest vitamin C content in A. digitata seeds with $A$. africana seed had the least Vitamin E composition of $0.74 \pm 0.01 \mathrm{mg} / 100 \mathrm{~g}$.

Table 2. Vitamin Contents in some Selected Wild Edible Seeds in the Study Area

\begin{tabular}{|l|l|l|l|}
\hline Tree specie & Vitamins $\mathbf{( m g / 1 0 0 ~ g ) ~}$ & & \\
\hline & \multicolumn{1}{|c|}{$\mathbf{A}$} & \multicolumn{1}{c|}{ C } & E \\
\hline A. africana & $4.56 \pm 0.03 \mathrm{a}$ & $138.72 \pm 0.52 \mathrm{a}$ & $0.74 \pm 0.01 \mathrm{a}$ \\
\hline A. digitata & $322.50 \pm 1.50 \mathrm{~b}$ & $522.50 \pm 1.50 \mathrm{~b}$ & $429.00 \pm 2.00 \mathrm{~b}$ \\
\hline T. cattapa & $0.91 \pm 0.00 \mathrm{c}$ & $0.05 \pm 0.00 \mathrm{c}$ & $19.66 \pm 0.2 \mathrm{c}$ \\
\hline
\end{tabular}

Means on the same column with different superscript differ significantly $(P<0.05)$

\section{DISCUSSION}

Minerals are important in the human diet because of their various functions in the body. They serve as cofactors for many physiologic and metabolic functions. The calcium contend of A. digitata seeds were found to be the least $(81.08 \pm 0.05 \mathrm{mg} / 100 \mathrm{~g})$ while $T$. cattapa was the highest with $789.61 \pm 0.01$ $\mathrm{mg} / 100 \mathrm{~g}$ (Table 1). This value is low when compared to $900 \mathrm{mg} / 100 \mathrm{~g}$ obtained from Benni seed [9]. The dietary allowance for calcium is $800 \mathrm{mg}$ for $70 \mathrm{~kg}$ man [10]. This shows that almond can supplement other sources of dietary calcium since it is consumed mainly as snack [11]. Calcium is an important mineral require for bone formation and neurological function. Calcium deficiency in children leads to rickets, while in adults it may results in osteomalacia. As rickets is a common problem in the Africa, calcium intake is especially important for children who live in this part of Africa [12].

The highest potassium content of the selected edible forest seeds of $723.50 \pm 3.50 \mathrm{mg} / 100 \mathrm{~g}$ was determined in T. cattapa seeds. Akpabio [13] recorded $350.00 \mathrm{mg} / 100 \mathrm{~g}$ of potassium in almond seed. This value is high when compared to $330 \mathrm{mg} / 100 \mathrm{~g}$ obtained for cocoa bean [14]. The dietary allowance for potassium is $(1875 \mathrm{mg}-5625 \mathrm{mg})$ for adults [10]. The seed could be recommended as source of dietary supplement for potassium.

The magnesium content was high from $T$. cattapa seed $(687.58 \pm 0.01 \mathrm{mg} / 100 \mathrm{~g})$, while A. africana seed was the lowest with $3.59 \pm 0.01 \mathrm{mg} / 100 \mathrm{~g}$ magnesium content, even though it was found to be the 
lowest, yet it is high and recommended when compare to 0.13 obtained for Zea mays [15]. The element is an essential part of many enzyme systems and is also important in maintaining the electrical potential of nerve and muscle membranes [11].

The phosphorus content obtained from the selected seeds had $9.48 \pm 0.01 \mathrm{mg} / 100 \mathrm{~g}$ as the lowest phosphorus content from $A$. africana seeds. The dietary allowance for phosphorus is $800 \mathrm{mg} / 100 \mathrm{~g}$ [10]. Therefore A. africana seeds cannot be recommended as phosphorus supplements. Phosphorus a macronutrient comprises 22 percent of the total minerals of the body. Dietary deficiency of phosphorus is extremely unlikely as nearly all food content this mineral [11].

The value of $422.00 \pm 1.00 \mathrm{mg} / 100 \mathrm{~g}$ was obtained as Iron content from $T$. cattapa seed, while A. africana seed had the lowest content $(3.49 \pm 0.03 \mathrm{mg} / 100 \mathrm{~g})$. The Iron content in $T$. cattapa seed is high when compared to $1.94 \mathrm{mg} / 100 \mathrm{~g}$ obtained for cocoa bean [14], when compared to $50 \mathrm{mg} / 100 \mathrm{~g}$ obtained for Benni seeds [9]. The dietary allowance for iron is $10 \mathrm{~g}$ for $70 \mathrm{~kg}$ ([10. Therefore, $T$. cattapa seed could be recommended as a dietary supplement for people who need iron and those dwelling in the rural areas that live in poverty and even urban dwellers. This shows that these seeds are very rich in iron. Iron is very important for the formation of haemoglobin and normal functioning of the central nervous system [16]. The Iodine content of the selected seeds was evaluated A. africana seed contents $134.04 \pm 0.03 \mathrm{mg} / 100 \mathrm{~g}$. Therefore, A. africana can be recommended as a dietary supplement in the developing countries especially for the purpose of food security.

Based on the result on vitamins content of the study seeds, A. digitata tree seed has a high content of vitamin $\mathrm{A}$ and $\mathrm{C}$ among the evaluated forest seeds. This study is in accord with Savadogo et al., [17] which reported that $A$. digitata seed contain essential nutrients for human good health and is important food. Thus, it is a dietary source of Vitamins A and C for human body and useful dietary supplements. The vitamin $\mathrm{A}, \mathrm{C}$ and $\mathrm{E}$ contents in these selected forest seeds are adequate to supplement other dietary sources. Vitamin A is a good treatment for people suffering from eye problem while deficiency of vitamin $\mathrm{C}$ leads to scurvy and gingivitis [11].

Fruits are good sources of vitamins A and C, which are lacking in many people's diets. Globally, children suffer from vitamin A deficiency, which can result in irreversible blindness. In Africa, low intake of vitamin A is considered to be the third greatest public health problem after HIV/AIDS and malaria. A. digitata which can be easily cultivated on farms in many tropical regions, contain high vitamin $\mathrm{A}$ and $\mathrm{E}$ contents. A. digitata fruit pulp has five times the vitamin $\mathrm{C}$ content of oranges. It also contains vitamins A, B1, B2 and B6, as well as several minerals, including calcium, phosphorus, potassium, iron, sodium, zinc and magnesium. In addition, its seed yield oil that is said to contain omega 3,6 and 9 fatty acids. The leaves as well as young stems and roots are eaten as vegetables, and are high in protein, vitamin A and iron [18].

\section{CONCLUSION AND RECOMMENDATIONS}

Based on this study, the selected edible wild seeds have high contents of mineral components such as calcium, potassium and iodine. A. africana and A. digital seeds have low iron content when compared with $T$. cattapa. Yet the seeds are very good sources of mineral nutrients for human body as useful dietary supplements. The wild tree seeds also contain essential vitamins for human good health. It is a dietary source of vitamins $\mathrm{A}, \mathrm{C}$ and $\mathrm{E}$ for human body. The high content of minerals and vitamins of the seeds and their availability in the forest indicates its potentials usefulness for human body especially in the developing countries which could reduce the level of mal-nutrition in most impoverished communities in Africa.

It is recommended, that extension services, NGOs, Government and schools centers should sensitize people on the benefits of forest and products. Also, promote the consumption of nutritious wild foods within their programs in order to eliminate negative perceptions and attitudes to forest tree fruits and seeds. Also, study should be carryout to assess the availability of these wild tree seeds and possible present of anti-nutrients.

\section{REFERENCES}

[1] Sadik, N., population growth and food crisis. food, nutrition and agriculture/alimentation, Nutrition et Agriculture; 1991, 1: 3-62.

[2] Pelletier, D. L., the potentiating effects of malnutrition on child mortality: epidemiologic evidence and policy implications. Nutrition Rev; 1994, 52: 409-15 
[3] Felger, R.S., ancient crops for the twenty-first century. In: Ritchie G.A, Gary A, eds. New agricultural crops. AAAS selected symposium 38 boulder, col, USA; 1979.

[4] Viano J. Masotti V., Gaydou E.M, Bourreil PJL, Ghiglione, Giraud M., compositional characteristic of 10 wild plant legumes from Mediterranean French pastures. Journal of Agriculture Food Chem, 43:680; 1995.

[5] Wu, G., Dietary protein intake and human health: A review, Food and Function, Royal society of chemistry; 2016, $7: 1251-1265$

[6] Association of Official Analytical Chemists (AOAC), Official method of analysis of the Association of official Analytical Chemist, 5th ad. AOAC Press, Arlington, Virginia, USA, 1990.

[7] Association of Official Analytical Chemists (AOAC), Official methods of analysis, 18th ed. Association of Official Analytical Chemists, Washington DC, 2005.

[8] Pearson, D., Chemical analysis of foods, 7th ed. Churchill Livingstone, London, 1976.

[9] Dashak, D. A. and Fali, C. N., Food Chemistry; 1993, 47: 53-75.

[10] National Research Council, Food and Nutrition Board; Recommended Dietary Allowances. 8 th edition. National Academy of Science, 1989: 20- 32

[11] Agatemor C. and Mark, E. U., Nutritional Potential of the Nut of Tropical Almond (Terminalia Catappia L.); Pakistan Journal of Nutrition; 2006, 5 (4): 334-336, ISSN 1680-5194

[12] Scariano, J.K., E.A. Walter, R.H. Glew, B.W. Hollis, A. Henry, I. Ocheke and C.O. Isichei, Serum Levels of the Pyridinoline Crosslinked Carboxyterminal Telopeptides of Type 1 Collagen (ICTP) and Osteocalcin in Rachitin Children in Nigeria. Clinical Biochemistry, 1995, 28: 541- 545

[13] Akpabio, U. D., Evaluation of proximate composition, mineral element and anti- nutrient in almond (Terminalia cattapa) seeds. Advances in Applied Science Research; 2012, 3 (4): 2247-2252 ISSN: 0976-8610. CODEN (USA): AASRFC, Pelagia Research Library www.pelagiaresearchlibrary.

[14] Olaefe, J. O., Nigerian trees, Annual of Botany; 1987, 14: 159-161.

[15] Amata, I.A and Nwagu, K.M., comparative evaluation of the nutrient profile of the seeds of four selected tropical plants and maize. International Journal of Applied Biology and Pharmaceutical Technology; 2013, 4 (1); 200-204; ISSN: 0976-4550; www.ijabpt.com

[16] Vyas, D. and R.K. Chandra, Iron nutrition in infancy and childhood. Nestle Nutrition Edn., pp: 21-25. Zewel, M.B., 1977; Dietary pattern and hypertension. DASH Stud. Nutr. Rev.; 1984, 55: 303-305.

[17] Savadogo, A.; Zongo, C.; Bayala, B.; Somda, K. M. and Traoré, A. S., Nutritional potentials of Cucumeropsis edulis (Hook. f.) Cogn seeds and the pulp of Adansonia digitata L. from Burkina Faso: Determination of chemical composition and functional properties, International Food Research Journal; 2011, 18(4): 1409-1414.

[18] Jamnadass R, Place F, Torquebiau E, Malézieux E, Iiyama M, Sileshi GW, Kehlenbeck K, Masters E, McMullin S, Dawson IK., Agroforestry for food and nutritional security In: Unasylva 241; 2013,64 (2), FAO, Rome Italy.

Citation: Dawaki. S.A et al., "The Nutritional Contributions of Some Forest Edible Seeds to Food Security", International Journal of Forestry and Horticulture (IJFH), vol. 3, no. 3, p. 5, 2017. http:// dx.doi.org/10. 20431/2454-9487.0303003

Copyright: (C) 2017 Authors. This is an open-access article distributed under the terms of the Creative Commons Attribution License, which permits unrestricted use, distribution, and reproduction in any medium, provided the original author and source are credited. 